\title{
To the biology of Hesperinus ninae Papp et Krivosheina, 2010 (Diptera: Hesperinidae) with description of immature morphology
}

\author{
К биологии Hesperinus ninae Papp et Krivosheina, 2010 (Diptera: \\ Hesperinidae) с описанием преимагинальных стадий
}

\author{
N.P. Krivosheina, M.G. Krivosheina \\ Н.П. Кривошеина, М.Г. Кривошеина
}

\begin{abstract}
A.N. Severtsov Institute of Ecology and Evolution, Russian Academy of Sciences, 33 Leninsky prospect, 119071 Moscow, Russia. E-mail: kriv2260@rambler.ru

Институт проблем экологии и эволюции им. А.Н. Северцова РАН, Москва 119071, Ленинский пр., 33, Россия.
\end{abstract}

KEY WORDS: Diptera, Hesperinus, ninae, rohdendorfi, biology, larvae, description, key.

КЛЮЧЕВЫЕ СЛОВА: Diptera, Hesperinus, ninae, rohdendorfi, биология, личинки, описание, определительная таблица.

ABSTRACT. Tha data on the biology and description of the larvae of Hesperinus ninae Papp et Krivosheina, 2010 are given for the first time. The description of the larvae of $H$. rohdendorfi Krivosheina et Mamaev, 1967 is expanded. Key to larvae of Hesperinus species is composed.

РЕЗЮМЕ. Впервые приводятся сведения по биологии и описывается личинка Hesperinus ninae Papp et Krivosheina, 2010. Дополнено описание известной ранее личинки $H$. rohdendorfi Krivosheina et Mamaev, 1967. Составлена определительная таблица для видов рода Hesperinus по личинкам.

\section{Introduction}

The family Hesperinidae with the only genus Hesperinus Walker, 1848 represents one of the relict groups of Diptera, close to the families Cramptonomyiidae, Pachyneuridae and Pleciidae. Some authors treated it as subfamily of Bibionidae [Hardy and Takahashi, 1960; Hardy, 1981] though others considered it as separate family [Hendel, 1928, 1936; Hennig, 1948, 1954; Rohdendorf, 1964, 1977; Krivosheina \& Mamaev, 1967; Krivosheina, 1969, 1997]. Eight species of Hesperinus are known worldwide, six of them were registered in Palaearctic region. H. imbecillus (Loew, 1858) is known from Central and South Europe, $H$. ninae Papp et Krivosheina, 2010 - from North Caucasus (Russia), $H$. graecus Papp, 2010 — from Greece, H. rohdendorfi Krivosheina et Mamaev, 1967 — from East Siberia and Far East of Russia, H. cuspidistylus Hardy et Takahashi, 1960 and H. nigratus Okada, 1934 - from Japan (Hokkaido). One species - H. brevifrons Walker, 1848 was described from Canada and one species - H. conjugens Schiner, 1868 — from Brasilia [Mohrig et al., 1975; Okada, 1934; Papp, 2010; Papp \& Krivosheina, 2010].
Adults of Hesperinus represent long-legged and long-winged flies with significantly elongated antennae. Usually they are collected in early spring by sweeping above low vegetation; nobody observed males forming swarms. They have one generation per year. Data on larval habitats were studied for $H$. rohdendorfi only [Krivosheina and Mamaev, 1967]. Xylophagous larvae of the abovementioned species bred in decaying wood of deciduous trees; larvae were boring dead rotten wood of Alnus, Betula, Chosenia and inhabited mainly fallen branches, slender trunks and stumps. Larvae were never found under the bark. Generally Hesperinidae larvae resemble those of Bibionidae but its body is without conical projections.

The specimens of $H$. ninae were collected in Krasnaya Polyana, Medvezh'i Vorota and firstly were attributed to H.imbecillus [Mohrig et al., 1975]. The authors considered 3 forms of this species - from Austria, Venezian Alps and North Caucasus which differed by details of the morphology of apical palpomere and pubescence of gonostylus.

\section{Description of larva}

Hesperinus ninae Papp et Krivosheina, 2010 Figs 1-12.

MATERIAL. 3 larvae, 1 pupa, 1 female, 1 male. Krasnodarsky Kray, Krasnaya Polyana, Medvezh'i Vorota, N 207, 30.08.1966. In wood of beech Fagus orientalis.

DESCRIPTION. Body length $12 \mathrm{~mm}$.

Head oval, dark-brown. Head capsule is almost closed ventrally, lateral sclerites are narrowly separated. Frontal plate with 4 distinct conical lateral projections each bearing 1 long seta. Frontal plate 2/3 as long as the head capsule. Lateral plates with three dorsal setae of different size at anterior part. Clypeus and labrum are less sclerotized and look lighter than the 


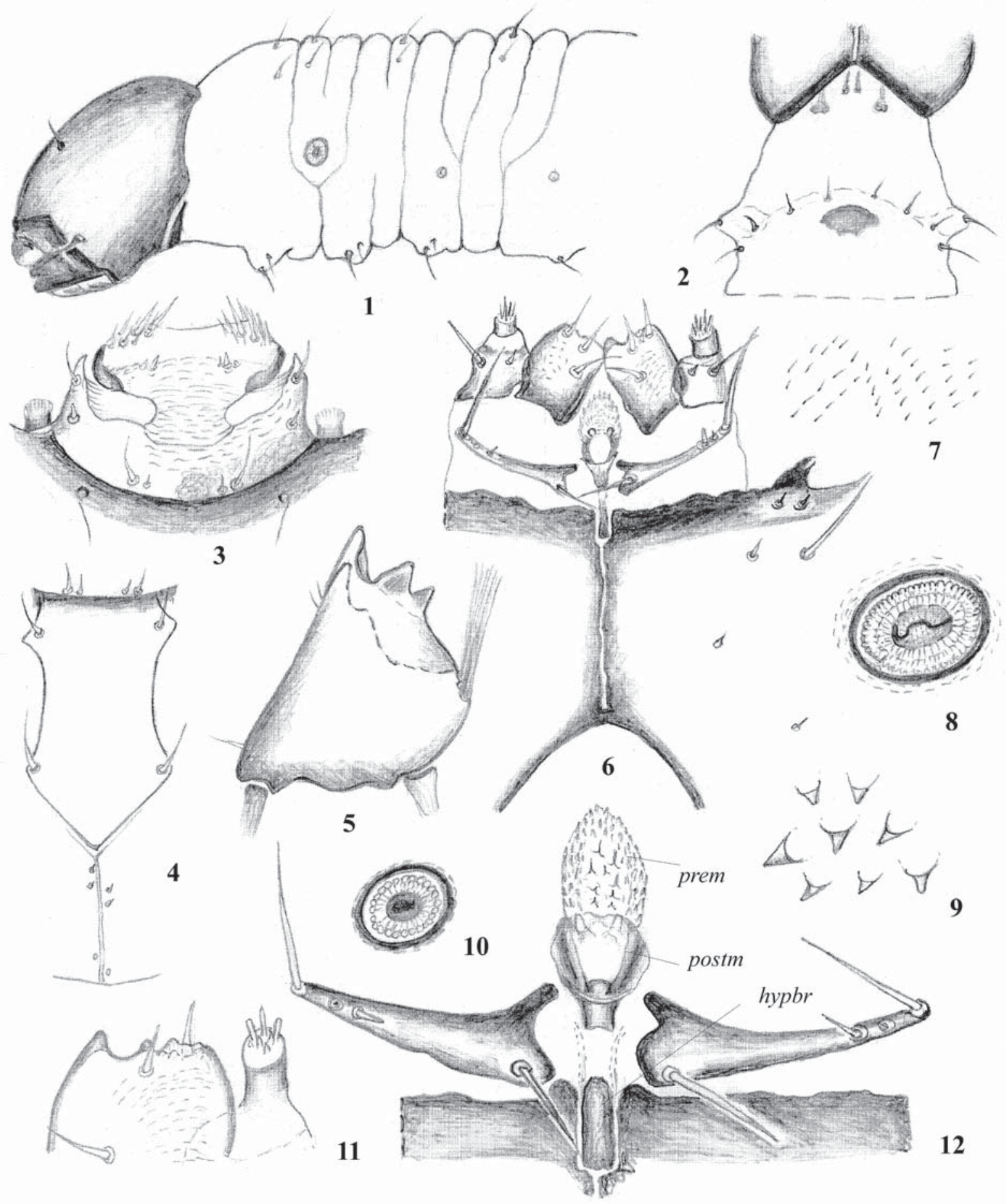

Figs 1-12. Larva of Hesperinus ninae Papp et Krivosheina, 2010: 1 - head and thoracic segments, lateral view; 2 - prothoracic segment, ventral view; 3 - labrum and clypeus; 4 - frontal plate; 5 - mandible; 6 - middle of head, ventral view; 7, 9 - cuticular structures of integument: 8 - posterior spiracle; 10 - anterior spiracle; 11 - anterior part of maxilla; 12 - anterior part of the head capsule, ventral view. Abbreviations: hypbr - hypostomal bridge; prem - prementum; postm - postmentum.

Рис. 1-12. Личинка Hesperinus ninae Papp et Krivosheina, 2010: 1 - голова и грудные сегменты сбоку; 2 - переднегрудной сегмент, снизу; 3 - верхняя губа и клипеус; 4 - фронтальная пластинка; 5 - мандибула; 6 - средний отдел головы снизу; 7, 9 - кутикулярные структуры покровов; 8 - заднее дыхальце; 10 - переднее дыхальце; 11 - передний край максилы; 12 передний отдел головной капсулы с вентральной стороны. Условные обозначения: $h y p b r$ - гипостомальный мостик; prem прементум; postm - постментум. 
head capsule (Fig.3). Clypeus with conical pointed anterolateral projections, each bearing 1 setae. One seta presents on lateral side of clypeus and 2 pairs of setae - along its posterior margin. Anterior part of clypeus with wrinkled surface and transverse folds, no distinct border between clypeus and labrum. Anterior part of labrum light with a group of long and short setae on anterolateral angles and 2 groups consisting of 3-4 short conical setae at middle. Posterior part of labrum is wrinkled like clypeus.Mandibles sclerotized with 4 distinct dents and 1 small oval indistinct. Prostheca like a bunch of long dense setae (Fig. 5). Maxilla with massive almost rectangular lacinia and adjoined stypes bearing one-segmented palpus. Cardo elongate, narrow, bifurcate and broaded internally. Exterior margin with 2 short conical setae and marginal long seta reaching the apex of maxillar palpus (Fig. 6). Lacinia with conical anterior dent and 2 small projections; 2 large setae are situated near them (Fig. 11). The third longer setae is attached in the middle of lacinia. Stypes with long and short setae near the base of palpus. Palpus short with many apical papillae. Labium consists of prementum and postmentum; the former like oval unsclerotized lobe with short setulae at periphery, the latter like 2 sickle-like fused basally lateral plates confining transparent area with 2 large papillae (Fig. 12). Narrow sclerotized plate at the anterior part of the head capsule between lateral plates is considered as hypostomal bridge [Teskey, 1981]. Hypopharynx massive and unclerotized, carrying many short spinules, and supported by lateral almost triangular plates beginning from medial ventral part of labium (like on Fig. 23). Antennae short, with fan-situated 7-8 anterior papillae and slightly flattened dorsoventrally.

Body consists of 3 thoracic and 9 abdominal segments. Integument covered with conical spinules mainly on ventral surface and groups of microspinules on prothorax (Figs 9, 7). Prothorax with additional dorsal fold, separating the part of the segment carrying anterior spiracles (Fig. 1). Posterior segment of the body is also secondary divided in 2 subsegments; anterior is lacking setae and is wider than the posterior one. Prothorax with 4 pairs of dorsal setae regulated in 2 rows. Thoracic segments II-III and abdominal segments IVII with 4 pairs of setae forming 1 row. 3 pairs of setae present on abdominal segment VIII at the level of spiracles. Last body segment without setae anteriorly; posterior part carries 3 pairs of setae forming inclined row. Prothorax ventrally with 2 rows of setae, the former with 3 pairs and the latter - with 1 pair. All the other body segments ventrally with 3 pairs of setae, including segment IX.

Tracheal system of holopneustic type. Spiracles are situated on lateral surface of pro- and metathorax as well as on 8 abdominal segments (Fig. 1). Last body segment without spiracles. Spiracles with large central disc and many spiracular chambers at the periphery. Peritrema well developed, dark (Figs 8, 10), the first and the last spiracles are the largest. Spiracles oval; posterior spiracle a little displaced dorsally.

DIAGNOSIS. Body surface bearing weakly developed conical microspinules mainly along the borders of the segments. Prothorax with microspinules on anterior part. Hypostomal bridge narrow and long. Cardo with anterior long internal projection. Base of postmentum not widened (Fig. 6).

BIOLOGY. Larvae inhabited brown fragile wood of fallen beech Fagus orientalis where they were discovered at periphery of the trunk together with larvae of Symmerus annulatus (Meigen, 1830) (Ditomyiidae). 1967

Hesperinus rohdendorfi Krivosheina et Mamaev, Figs 13-23.

MATERIAL. 3 larvae, 2 males. Primorskiy Kray, Ussurijskiy Preserve, 12.04.1967, N 21, in Ulmus wood.

DESCRIPTION. Body length $12 \mathrm{~mm}$.

Head almost black completely (Fig. 13). Frontal plate of the head capsule elongate, as long as $2 / 3$ of the head capsule or a little longer. Frontal plate with 2 pairs of well-developed setae the posterior of which are the longest. Lateral plates of the head capsule with three pairs of dorsal setae. The head capsule is almost closed ventrally (Fig. 14). Hypostomal bridge massive, almost square or rectangular (Fig. 15). Clypeus with one seta on each conical lateral projection, with small setae on lateral surfaces and 2 pairs of setae - near its posterior margin (Fig. 16). Anterior part of clypeus with wrinkled surface. Anterior lateral part of labrum with 3 long and a group of short setae. Posterior half of labrum is wrinkled like clypeus. Ventral surface of labrum with groups of small spinules. Mandibles with massive prostheca and 5 distinct apical pointed dents (Fig. 20). Stipes of maxilla with 2 large ventral setae. Lacinia with 1 large ventral seta and a group of small dorsal spinules (Figs 19, 22). Its anterior margin with additional internal dent and larger projections than in H.ninae. Cardo with weakly developed anterior internal projection. Labium consists of prementhum and postmenthum; postmenthum with broaded base.

DIAGNOSIS. Body surface bearing weakly developed conical microspinules regularly distributed on all segments (Fig. 21). Hypostomal bridge massive, square or rectangular. Cardo with weakly developed short anterior internal projection. Base of postmenthum widened.

BIOLOGY. Larvae inhabited decomposed but with retained structure solid light wood of stumps and fallen trunks, sometimes devoid of bark, of deciduous trees (Maackia amurensis, Ulmus propinqua, Chosenia arbutifolia, Betula sp. and others) where the larvae formed small colonies to 20 specimens [Krivosheina, 1972]. In case of large trunks the larvae inhabit periphery. As a rule they are found together with larvae of Symmerus brevicornis Okada, 1939 (Ditomyiidae). 


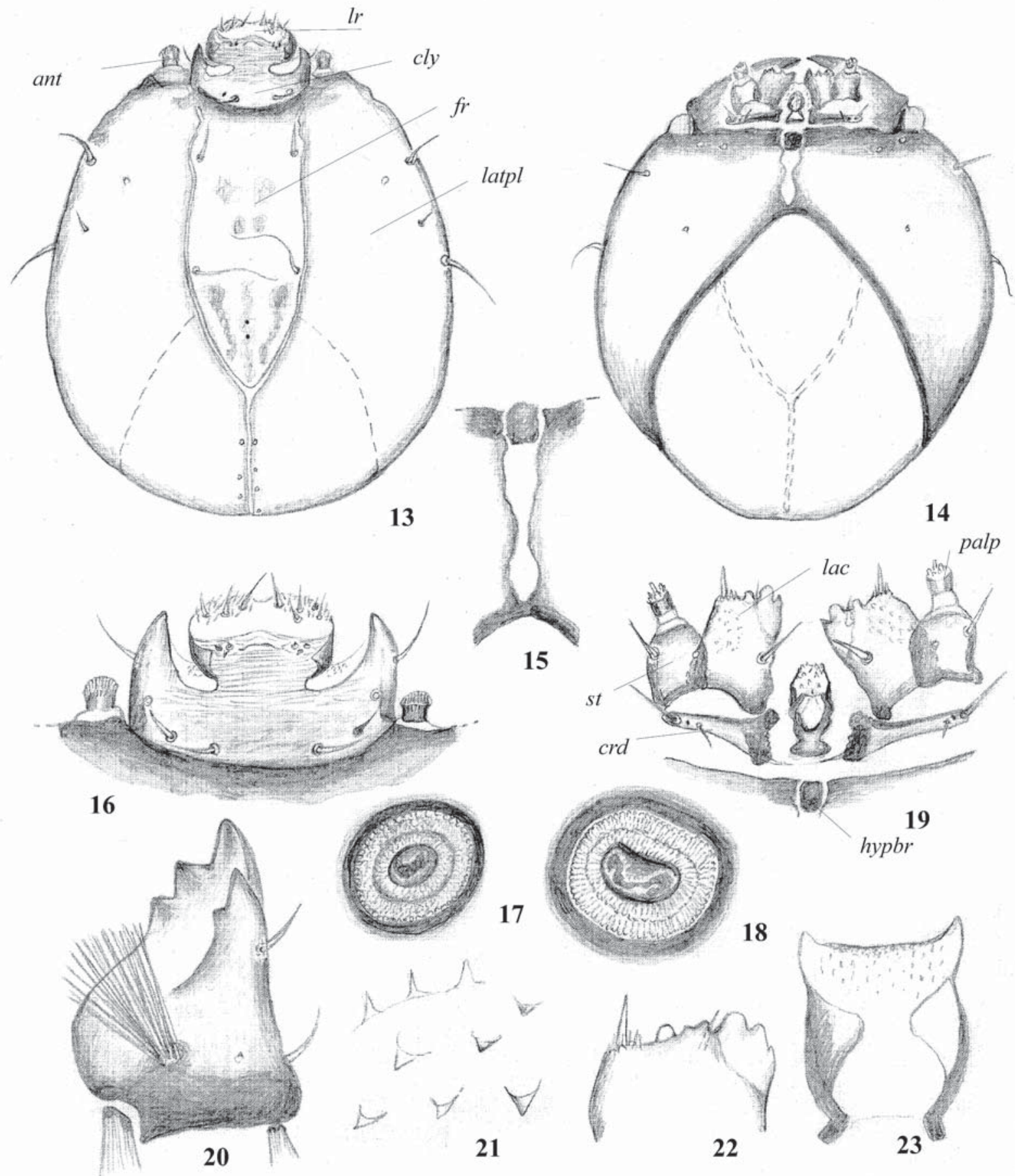

Figs. 13-23. Larvae of Hesperinus rohdendorfi Krivosheina et Mamaev, 1967: 13, 14 - head, dorsal and ventral views; 15 hypostomal bridge; 16 - labrum and clypeus; 17, 18 - anterior and posterior spiracles; 19 - maxilla and labium; 20 - mandible; 21 cuticular structures of integument; 22 - anterior part of lacinia; 23 - hypopharynx. Abbreviations: ant - antenna; cly - clypeus; crd cardo; fr - frontal plate; lac — lacinia; latpl - lateral plate; l $r$ - labrum; palp - palpus; st - stypes; others as on Figs. 1-12.

Рис. 13-23. Личинка Hesperinus rohdendorfi Krivosheina et Mamaev, 1967: 13, 14 - голова сверху и снизу; 15 — гипостомальный мостик; 16 - верхняя губа и клипеус; 17, 18 - заднее и переднее дыхальца; 19 - максиллы и нижняя губа; 20 - мандибула; 21 - кутикулярные структуры покровов; 22 - передний край лацинии; 23 - гипофаринкс. Условные обозначения: ant - антенна; cly - клипеус; crd — кардо; fr - фронтальная пластинка; lac — лациния; latpl — латеральная пластинка; $l r$ — верхняя губа; palp — щупик; st - стипес; остальные как на рис.1-12. 


\section{Key to larvae of Hesperinus Walker, 1848}

- Body surface bearing weakly developed conical microspinules mainly along the borders of the segments. Prothorax with microspinules on anterior part. Hypostomal bridge narrow and long. Cardo with anterior long internal projection. Base of postmentum not widened .. H. ninae Papp et Krivosheina, 2010

- Body surface bearing weakly developed conical microspinules regularly distributed on all segments. Hypostomal bridge massive, square or rectangular. Cardo with weakly developed short anterior internal projection. Base of postmenthum widened

$$
\text { H. rohdendorfi Krivosheina et Mamaev, } 1967
$$

ACKNOWLEDGEMENTS. The work was fulfilled with financial support of RFBR, project no. 14-04-01116a.

\section{References}

Hardy D.E. 1981. Bibionidae // McAlpine J.F. et al. (eds.). Manual of Nearctic Diptera. Monograph No.27. Vol.1. Ottawa: Research Branch Agriculture Canada. P.217-222.

Hardy D.E., Takahashi M. 1960. Revision of the Japanese Bibionidae // Pacific Insects. Vol.2. No.4. P.384-449.

Hendel F. 1928. Zweiflugler oder Diptera. II. Allgemeiner Teil // Dahl F. (Hrsg.). Die Tierwelt Deutschlands. Jena: Gustav Fisher Verlag. S.1-135.

Hendel F. 1936. Handbuch der Zoologie. Berlin und Leipzig. Bd.4 S.1729-1998.

Hennig W. 1948. Die Larvenformen der Dipteren. Bd. I. Berlin. S. $1-360$.

Hennig W. 1954. Flügelgeäder und System der Dipteren unter Berücksichtigung der aus dem Mesozoikum beschriebenen Fossilien // Beitrag zur Entomologie. Bd.4. Hf.3/4. S.246-388.
Krivosheina N.P. 1969. [Onthogeny and evolution of Diptera]. Moscow: Nauka. 291 pp. [in Russian].

Krivosheina N.P. 1972. [Detritophilous dipterans of the bibionoid complex in Southern Primorie (Diptera, Nematocera)] // Ivliev L.A., Konovalova Z.A. (eds.). The role of insects in forest biocenoses of Primorje. Trudy Biologo-Pochvennogo Instituta. N.S. Vol.7. No.110. P.159-170 [in Russian].

Krivosheina N.P. 1997. Family Hesperinidae // Papp L., Darvas B. (eds.). Contributions to a Manual of Palaearctic Diptera. Vol.2. Nematocera and Brachycera. Budapest: Science Herald. P.35-41.

Krivosheina N.P., Mamaev B.M. 1967. [New data on the families Hesperinidae and Pachyneuridae and their position in the order Diptera] // Zoologicheskiy Zhurnal. Vol.56. No.2. P.235247 [in Russian].

Mohrig W., Mamaev B., Matile L. 1975. Zur Kenntnis flügelreduzierter Dipteren der Bodenstreu. VII. Beitrag: Gattung Hesperinus (Diptera, Hesperinidae) // Zoologischer Anzeiger. No.5/6. S.339-344.

Okada I. 1934-35. Ueber die gattungen Hesperinus und Pachyneura (Neue und wenig Bekannte Dipteren aus Japan I) // Insecta matsumurana. Vol.9. No.1-2. P.24-26.

Papp L. 2010. A study on Hesperinus Walker with description of a new species (Diptera: Hesperinidae) // Acta zoologica Academiae Scientiarum Hungaricae. Vol.56. No.4. P.347-370.

Papp L., Krivosheina M. 2010. Description of a new species of Hesperinus Walker, 1848 from the north Caucasus (Diptera: Hesperinidae) // Russian Entomological Journal. Vol.18 (for 2009). No.4. P.293-297.

Rohdendorf B.B. 1964. [Historical development of Diptera (Insecta)] // Trudy Paleontologicheskogo Instituta. Vol.100. P.1-311 [in Russian].

Rohdendorf B.B. 1977. [The classification and phylogeny of the Diptera] // Scarlato O.A., Gorodkov K.B. (eds.). Systematic and evolution of the Diptera (Insecta). Leningrad: Acad. Sci. USSR. P.81-88 [in Russian].

Teskey H.J. 1981. Morphology and terminology - larvae. McAlpine J.F. et al. (eds.). Manual of Nearctic Diptera. Vol.1. Research Branch Agriculture Canada. Monograph No 27. Ottawa. P.6588. 